\title{
ALPP wt Allele
}

National Cancer Institute

\section{Source}

National Cancer Institute. ALPP wt Allele. NCI Thesaurus. Code C107553.

Human ALPP wild-type allele is located in the vicinity of $2 q 37$ and is approximately $4 \mathrm{~kb}$ in length. This allele, which encodes alkaline phosphatase, placental type protein, is involved in placental alkaline phosphatase activity. 